\title{
Normative arguments for non-state actor participation in international policymaking processes: Functionalism, neocorporatism or democratic pluralism?
}

\author{
Naghmeh Nasiritousi, Mattias Hjerpe and Karin Bäckstrand
}

\section{Linköping University Post Print}

\section{Tweet}

N.B.: When citing this work, cite the original article.

Original Publication:

Naghmeh Nasiritousi, Mattias Hjerpe and Karin Bäckstrand, Normative arguments for nonstate actor participation in international policymaking processes: Functionalism, neocorporatism or democratic pluralism?, 2015, European Journal of International Relations. http://dx.doi.org/10.1177/1354066115608926

Copyright: SAGE Publications (UK and US)

http://www.uk.sagepub.com/home.nav

Postprint available at: Linköping University Electronic Press

http://urn.kb.se/resolve?urn=urn:nbn:se:liu:diva-123293 


\section{Normative arguments for non-state actor participation in international}

policy-making processes: Functionalism, neocorporatism or democratic pluralism?

Naghmeh Nasiritousi, ${ }^{1 *}$ Mattias Hjerpe ${ }^{1}$ and Karin Bäckstrand ${ }^{2}$

${ }^{1}$ Centre for Climate Science and Policy Research and Department of Thematic Studies Environmental Change, Linköping University, Sweden

${ }^{2}$ Department of Political Science, Stockholm University, Sweden

* Corresponding author:

Naghmeh Nasiritousi

Centre for Climate Science and Policy Research

Department of Thematic Studies - Environmental Change

University of Linköping

SE-581 83 Linköping, Sweden.

Email: naghmeh.nasiritousi@liu.se 


\begin{abstract}
The participation of non-state actors (NSA) in multilateral institutions is often portrayed as one way of decreasing the perceived legitimacy deficit in global governance. The literature on NSAs has identified several ways in which these actors can enhance the legitimacy of inter-governmental organisations and global governance arrangements. Three partially-competing normative arguments, or rationales, for the inclusion of nonstate actors in international policy-making - functionalism, neocorporatism and democratic pluralism - have been identified (Willetts, 2006). Whereas functionalism highlights the contribution of NSAs to output legitimacy in terms of expertise, neocorporatism emphasises the inclusion of affected interests, and democratic pluralism claims that NSAs increase input legitimacy through procedural values. These three normative arguments thus offer different understandings of the motives for inclusion and representation of NSAs in international negotiations and diplomacy. Through a single case study of UN climate diplomacy, we analyse the extent to which the three rationales for NSA inclusion are found in views held by state and non-state actors participating in the annual UN climate change conferences. Our results show that different actor groups place varying degrees of emphasis on the different rationales for NSA inclusion, even though the neocorporatist rationale remains most favoured overall. We discuss the implications of our findings for the democratic legitimacy of increasing participation of NSAs in intergovernmental affairs and recent trends in the participation of NSAs in the international climate change policy-making process.
\end{abstract}

\title{
Keywords
}

Legitimacy, non-state actors, global governance, climate change 


\section{Introduction}

In the past decades international policy-making processes have increasingly involved both state and non-state actors (NSA) (e.g. Charnovitz, 1997; Tallberg and Jönsson, 2010; Tallberg et al., 2013; Willetts, 2011). ${ }^{1}$ While proponents of NSA involvement in international affairs claim that this development increases the legitimacy of global governance (Dryzek, 2012; Scholte, 2011; Steffek et al., 2008; Stevenson and Dryzek, 2014), critics argue that NSAs are not a panacea for the democratisation of global governance as they are not accountable themselves and represent dominant interests (Anderson and Rieff, 2005; Brühl, 2010; Rieff, 1999). While the academic debates on the promises and pitfalls of NSA participation predominate, this article makes an empirical contribution by examining actors' perceptions of rationales for the inclusion of NSAs in international affairs. Understanding the arguments for involving NSAs in international policy-making amongst state and non-state actors participating in multilateral institutions is important for the theory and practice of global governance. By knowing how different actors value the legitimate roles of NSAs in international policy-making, we can gain insights into pertinent questions, such as how authority is shared between states and NSAs in global governance, and how this is likely to affect political outcomes.

\footnotetext{
${ }^{1}$ Other terms used are civil society actors, non-governmental organisations, private actors or transnational actors, see Bäckstrand (2015). Here we use the term non-state actor to mean any group participating in global governance that is not a sovereign state, while excluding armed and criminal groups.
} 
Our point of departure is Willetts (2006), who outlines three partially-competing normative arguments for the inclusion of NSAs in international affairs: functionalism, neocorporatism and democratic pluralism. Willetts' framework enables broad assessment of legitimacy arguments for non-state participation in international affairs, as it captures different rationales for including NSAs to enhance democratic legitimacy, effectiveness and performance of global governance. There is a large scholarship on the democratising potential of non-state actors and civil society (Dingwerth, 2007; Dryzek, 2012; Friedman et al., 2005; Scholte, 2011). Deliberative and discursive accounts of global democracy highlighting a vital transnational sphere of civil society have gained ground (Dryzek, 2006; Stevenson and Dryzek, 2014). Moreover, cosmopolitan models of democracy (Held, 1995) and stakeholder democracy (Macdonald, 2008) have been advanced to enhance the legitimacy of global governance. However, democracy is only one source of legitimacy of global governance along with effectiveness, fairness, peace, and stability. Consequently, we are attracted by Willetts' approach that encompasses different rationales for representation, participation and inclusion of NSAs beyond democratic legitimacy.

Whereas functionalism highlights the contribution of NSAs to output legitimacy in terms of expertise, neocorporatism emphasises the inclusion of affected interests, and democratic pluralism claims that NSAs increase input legitimacy through procedural values. They offer three different rationales for why NSAs should be involved in 
international affairs and highlight tensions between NSAs as apolitical, political, or democratic actors. These normative arguments in turn are linked to various models to enhance democratic legitimacy of global governance, such as notions of democratic intergovernmentalism or polycentrism (Archibugi et al., 2011), stakeholder democracy (Macdonald, 2008) and deliberative democracy (Dryzek, 2006). As theoretical rationales, they offer different views on the roles of states and NSAs in international policy-making processes and therefore have implications for our understanding of contemporary global governance arrangements.

To date there has been no systematic attempt to empirically measure how these rationales for NSA inclusion are perceived by participants involved in international policy-making processes. In this article we offer a novel empirical assessment of how these normative arguments for NSA inclusion are reflected in the views held by a range of actors, non-state and state actors alike, participating in the Conference of the Parties (COPs) of the United Nations Framework Convention on Climate Change (UNFCCC). This is in line with previous research (e.g. Friedman et al., 2005: 8) using UN summits on environment, human rights and women as "empirical test cases for the emergence and potentially democratizing impact of civil society". Global environmental politics is one of the policy domains that have the most developed mechanisms for access and participation of NSAs in negotiations (Steffek et al., 2008). The UN climate conferences have far-reaching mechanisms to include NSAs as observers (Nasiritousi and Linnér, 
2014; Willetts, 2011). In comparison with other policy fields, such as international trade, security, and finance, environmental politics is very inclusive and open in terms of access for NSAs and participatory and deliberative innovations (Bernstein, 2012).

This article, however, does not examine whether NSAs contribute to enhance the democratic legitimacy of global governance. Instead, we are interested in understanding the nature of NSA participation in international policy-making by exploring how the theoretical rationales correspond with actors' perceptions of why NSAs should be included. Departing from a sociological approach to legitimacy we empirically investigate how these rationales play out amongst actors participating in climate diplomacy. A sociological approach to legitimacy means that different actors may perceive of the rationale for including NSAs in the international policy-making process differently. Based on previous literature we outline expectations for how actors' support for different normative arguments for NSA inclusion can vary depending on their roles and geographical origin. The article thereby highlights the pertinent question of how the participation of NSAs in international policy-making is legitimised by various actors, which has implications both for the theory and practice of emerging systems of nonstate representation at the global level.

By utilising four consecutive years of survey data from the UNFCCC COPs, we will address the following research questions: 
- To what extent do the arguments of participants at the UN climate change conferences on NSA inclusion reflect the rationales of functionalism, neocorporatism or democratic pluralism?

- Do geographical origin and actor type, i.e., the respondents' primary role at these conferences, affect the extent to which the responses resonate with any of the three rationales?

The paper contributes to the scholarship on the legitimacy of NSAs in global governance by providing an empirical analysis of how state and different types of NSAs view and justify the contribution of NSAs in international policy-making processes. This, in turn, enhances our understanding of on what grounds NSAs increasingly participate in global governance institutions and offers insights into the type of participatory governance model preferred by a range of state and NSAs. This has implications for current debates about shifting state-non-state actor relations and prospects for transnational democracy (Bäckstrand, 2006).

This paper is organised as follows. Next, we will briefly survey the vast literature on legitimacy of NSA inclusion in global governance and elaborate the three partially-competing rationales for their inclusion: functionalism, neocorporatism and democratic pluralism. These are, in turn, linked to three governance models, which we denote intergovernmental neo-functionalism, stakeholder democracy and deliberative 
democracy. Based on observations from previous literature, we draw up expectations of why actors may favour different rationales for NSA inclusion. The succeeding section describes the study design, data collection and analysis. Thereafter we present our results regarding the overall reasons for NSA inclusion and whether geographical origin or role influences these rationales for inclusion. Subsequently, we discuss how our findings relate to broader discussions of global democracy - mainly global stakeholder democracy - and the current status of the negotiations under the UNFCCC. A final section concludes.

\section{Non-state actors and legitimacy}

Why should NSAs be included in international policy-making? From where do they draw their raison d'être? These questions have attracted a wide range of responses from both academic and policy circles. The responses generally fall into one of two main perspectives. In one version, states remain the main sources of authority and legitimacy on the world stage and thus NSA involvement in international affairs is neither desirable nor significant. The other side claims that globalisation dynamics have given rise to a reconfiguration of global authority whereby NSA participation can increase the legitimacy of global governance arrangements (Bernauer and Gampfer, 2013; Bernstein, 2005; Biermann and Gupta, 2011; Dombrowski, 2010). 
In studying legitimacy, two approaches can be discerned - normative or sociological legitimacy (Keohane, 2011). "To say that an institution is legitimate in a normative sense is to assert that it has the right to rule" whereas an "institution is legitimate in a sociological sense when it is widely believed to have the right to rule" (Buchanan and Keohane, 2006: 405). Normative legitimacy examines whether the justification of authority is well-founded whereas sociological or political legitimacy means the acceptance of the rule-making authority among constituencies. Sociological legitimacy prevails when authority and rule-makers have the consent of those who are subject to it, while normative legitimacy can be established if the authority conforms to pre-defined standards (Scholte, 2011: 111).

Normative legitimacy based on democratic theory emphasises the need for "accountability, transparency, access to participation, deliberation and, sometimes, fairness" (Bernstein, 2005: 147). Advocates of NSA participation in international policy-making processes stress the contribution of these actors to the democratic legitimacy for current global governance arrangements (Betsill and Corell, 2008; Biermann and Gupta, 2011; Dryzek, 2012). According to this view, decisions taken by states in intergovernmental settings increasingly affect people on the ground, not least in the fields of finance and the environment. The distance between citizens and decisions has therefore widened in a range of areas. This has challenged the democratic legitimacy of global governance (Bernauer and Gampfer, 2013; Bernstein, 2005; 
Biermann and Gupta, 2011). As a remedy, the inclusion of NSAs is proposed as a way to close the legitimacy deficit in international politics.

Beyond normative theories of the democratising force of NSAs, a sociological legitimacy approach contends that justifications for the inclusion of NSAs stem from the perceptions of the appropriateness of such practices (Bernauer and Gampfer, 2013; Bernstein, 2012). In this vein, legitimacy is conceived as "a generalized perception or assumption that the actions of an entity are desirable, proper, or appropriate within some socially constructed system of norms, values, beliefs, and definitions" (Suchman, 1995: 574). In other words, the inclusion of NSAs in international policy-making can be legitimating if such practices have come to be perceived as desirable or appropriate by a community of actors.

In global environmental politics in particular, a long history of inclusion of NSAs in various UN conferences (e.g. Clark et al., 1997; Carr and Norman, 2008; Hjerpe and Linnér, 2010) has led to the institutionalisation of various mechanisms for NSA participation in climate and sustainable development diplomacy (Bernstein, 2012). The COPs have been particularly open to NSA participation, especially when compared to the security or financial realms of international politics. At these meetings, NSAs accredited to the organisation are allowed to act as observers, granting them different forms of participation rights (Nasiritousi and Linnér, 2014). The inclusion of NSAs in 
institutions of environmental governance may thus represent a legitimation strategy to the extent that such practices have come to be perceived as appropriate by society.

Whether in fact NSA inclusion is perceived as appropriate and on what grounds NSA participation is viewed as desirable by the actors themselves, however, remains largely unexplored. This paper offers a novel empirical account of actors' arguments for NSA inclusion in UN climate diplomacy. We review three distinct normative arguments, or rationales, found in the literature for why NSAs should be included in international policy-making and explore which of these are supported by states and a range of NSAs.

\section{Functionalism, neocorporatism and democratic pluralism}

The literature on NSAs has identified a number of ways in which NSAs can contribute to increasing the legitimacy of intergovernmental policy-making processes and international organisations. Arguments have been made for how NSAs may improve problem-solving capacity by sharing information and expertise or contributing to the implementation of decisions, or how they may strengthen the democratic quality of decision-making processes by increasing transparency and giving voice to marginalised views (Raustiala, 1997; Scholte, 2004; Steffek et al., 2008; Willetts, 2006). In other words, NSAs may contribute to improving 'input' legitimacy by strengthening procedural values, or 'output' legitimacy by improving the performance of outcomes (Scharpf, 1997). 
Willetts (2006) has advanced three normative arguments for the inclusion of NSAs in international policy-making: functionalism, neocorporatism and democratic pluralism. Functionalism emphasises the expertise of NSAs, neocorporatism views them as representatives of affected interests, while democratic pluralism highlights the democratic potential of NSAs by voicing arguments that otherwise risk being unheard. The first rationale thus highlights NSAs' potential contributions to output legitimacy or performance, whereas the second stresses that inclusion of stakeholders or affected interest can contribute to both input and output legitimacy, and the third emphasises their role in strengthening input legitimacy. While NSAs may fulfil all three tasks, the models are nevertheless partially competing - and even incompatible with each other if implemented strictly and in antidemocratic forms (Willetts, 2006).

According to Willetts (2006: 312), functionalism strongly emphasises "the ability of experts to maximise welfare and to depoliticise decisionmaking." This rationale thus relies on expert-driven decision-making as a source of legitimacy. It favours the inclusion of NSAs, such as epistemic communities (Haas, 1992), in international policy-making processes based on the view that they can deliver apolitical or impartial information and expertise to strengthen evidence-based decision-making. This rationale is thus results-oriented with an emphasis on NSAs as providers of specialist knowledge of a technical nature intended to aid states in taking 'better' decisions (Willetts, 2006). The early thinkers of functionalism (Burton, 1975; Mitrany, 
1975) were critical of intergovernmentalism, the dominant contemporary practice of global governance. Legitimacy in this vein stems from intergovernmental negotiations among sovereign states that have the formal decision-making authority (Bäckstrand, 2012). In contrast to the original functionalist rejection of intergovernmentalism, intergovernmental neo-functionalism emphasises a role for NSAs to channel their voices and expertise to decision-makers to improve the performance and effectiveness of multilateralism. The EU, UN agencies, and multilateral organisations have in practice adopted models of intergovernmental neo-functionalism whereby governments stress the procedural values of inclusion and participation of NSAs that hold special knowledge or expertise as contributing to output effectiveness. Mechanisms to include NSAs or their expert knowledge by governments and intergovernmental organisations thereby represent a legitimation strategy.

Neocorporatism, on the other hand, emphasises the value of involving sectoral interests in decision-making processes as a way of ensuring buy-in of policies. Thus rather than providing expertise and information, the role of NSAs, according to the neocorporatist rationale, is perceived to be representing interests that have an important stake in the decisions, as these groups can improve outcomes by engaging in popular mobilisation, aiding in implementing decisions and creating change on the ground. It is linked to "stakeholder democracy" (Bäckstrand, 2006; Maconald, 2008) models where legitimacy and effectiveness are enhanced through the institutionalised participation and 
representation of various stakeholders across market and civil society spheres. This rationale acknowledges that interests may often be in conflict with each other and views states as the arbitrators of political conflicts (Willetts, 2006). Thus, in contrast to the functionalist rationale, NSAs are here viewed as political agents in their own right.

While the neocorporatist rationale favours a multitude of stakeholder interests to be heard, it is not concerned about whether marginalised views are included. The democratic pluralist rationale, in contrast, emphasises the democratising potential of civil society and other NSAs through the strengthening of procedural values, such as transparency, representation, inclusion and accountability (Scholte, 2011; Steffek et al., 2008; Tallberg and Uhlin, 2011). It overlaps with participatory and deliberative models of global democracy. The former advances the transformative potential of civil society actors to participate and challenge unaccountable sites of power while the latter focuses on the role of civil society in establishing democratic control over the political discourse rather than institution building (Dryzek, 2006; Risse, 2004). A key component in the cultivation of transnational democratic spheres is to facilitate a public dialogue between agencies of public governance and those affected. International regimes can be conceived as sites for a transnational public sphere enabling deliberation between states and NSAs on norms on transparency, fairness and accountability (Payne and Samhat, 2004). Civil society plays a critical role in deliberative accounts of global democracy, in terms of the public scrutiny of arguments and debates over policy choices. Democratic 
pluralism contends that NSA inclusion brings about transparency of governments' bargaining positions and compliance records. Furthermore, NSA inclusion in international policy-making is claimed to enhance the representation and empowerment of marginalised societal groups, enabling opinions to be channelled to policy-makers that otherwise would risk being unheard.

In sum, NSAs may contribute to increasing the legitimacy of international policy-making processes by providing expertise, by representing interests with an important stake in the decisions, or by democratising global governance through participation and deliberation. Given that these three roles can at times clash, a pertinent question is which of these normative arguments for non-state inclusion is considered most important by a range of actors involved in the international policy-making process. A sociological approach to legitimacy means that different actors may perceive of the desirability and appropriateness of including NSAs in the international policy-making process differently. According to Bernstein (2005: 157), “different audiences of state, global civil society, or marketplace actors may share different criteria or weightings of 'input' (procedural), 'output' (performance, efficiency), or more traditional notions of 'substantive' (values of justice and fairness) legitimacy." How these weightings may differ between actors, however, remains largely unexplored. Building on different strands in the literature, the next section seeks to unpack factors that may affect perceptions of the appropriateness and desirability of NSA inclusion. 


\section{Appropriateness and desirability of non-state actor inclusion}

NSAs have long sought to make a mark on the state-dominated international system, where any involvement of NSAs in international affairs could be viewed by states as having some costs to state sovereignty (Cerny, 2010; Tallberg, 2010). Nevertheless, states increasingly involve NSAs in international policy-making. One reason why states have extended access to NSAs to participate in intergovernmental meetings is the development of a 'participatory norm' in global governance in general, and at UN conferences in particular, which may affect perceptions of the appropriateness of including NSAs (Bäckstrand, 2006; Willetts, 2011). Another reason is that states often value the contributions that NSAs make to the international policy-making process when allowed to participate, such as providing expertise or facilitating the implementation of decisions (Nasiritousi and Linnér, 2014; Raustalia, 1997; Tallberg, 2010). In general, therefore, we expect that few states and NSAs involved in global environmental negotiations would overtly oppose including NSAs. ${ }^{2}$

While we expect very few of our survey participants to answer that NSAs should not be included in international policy-making, previous literature gives us little guidance on how support for the different rationales is likely to differ between groups.

\footnotetext{
${ }^{2}$ Nevertheless, arguments for NSA inclusion may differ among state representatives depending on domestic political systems, such that countries with limited internal civil society engagement may be more suspicious of general NSA involvement (Nasiritousi and Linnér, 2014).
} 
The factors that affect perceptions among states and NSAs alike on why NSA inclusion is viewed as desirable have received scant attention in the literature (Bernstein, 2005). Nevertheless, we base our expectations of which rationales different actors are more likely to favour on observations in the available literature. For example, we assume that state representatives' perceptions of why NSAs should be included in international policy-making processes are closely linked to how they perceive NSAs' key roles in, and contributions to, international policy-making (Nasiritousi and Linnér, 2014), where the provision of expertise by NSAs has been highlighted as being particularly relevant to states (Raustalia, 1997; Tallberg, 2010). Generally, we can expect that government representatives are concerned about state sovereignty and therefore supportive of intergovernmental neo-functionalism, thereby favouring a functionalist rationale to NSA inclusion.

Different groups of NSAs may perceive the desirability question differently depending on the grounds for which they claim legitimacy in international affairs and their comparative advantage in different governance functions. For example, the views of business representatives can be expected to be more in line with the neocorporatist rationale based on their comparative advantage of representing what is generally held as an important interest that can affect change on the ground (see Nasiritousi et al., 2014a). Researchers may, conversely, be assumed to argue on the basis of a functionalist rationale as they generally claim legitimacy based on providing scientific expertise. 
Environmental NGOs may either be expected to ascribe to the neocorporatist rationale if we assume that they view themselves as representatives of important interests, namely safeguarding the environment, and that they can ensure buy-in for the decisions taken, the functionalist rationale if they view themselves as providers of information and expertise, or the democratic pluralist rationale if they view themselves as representing marginalised voices (Gough and Shackley, 2001). Representatives of local governments view themselves as "governmental stakeholders" (Adams and Pingeot, 2013: 12) and can thus be expected to respond in line with the neocorporatist rationale.

Another factor that may affect preference for the different rationales for NSA inclusion is geographical origin, such that actors from regions with more decentralised government systems may in general be more supportive of neocorporatism than regions with more centralised government systems. Moreover, the arguments of actors from regions that perceive themselves as being in the periphery of the global economic system, may in general be more supportive of the democratic pluralist rationale that emphasises the inclusion of marginalised voices. Within the context of climate change negotiations, several actors have claimed to be marginalised, for instance, least developed countries, indigenous peoples' organisations, as well as certain segments of the general public such as women, children and the urban poor.

While these expectations are tentative, the discussion above highlights that there are reasons to expect support for the different rationales for NSA inclusion to vary 
between actors depending on their roles and geographical origin. By exploring this question empirically we can enrich the understanding for how views about NSAs' roles and contributions to international affairs diverge and assess actual legitimacy demands (Bernstein, 2012).

\section{Examining arguments for non-state inclusion: Data and methods}

In this article we empirically assess perceptions of why NSAs should be included in international policy-making processes. Our case study is the intergovernmental negotiations on climate change, which have developed more advanced mechanisms for including NSAs compared to those in other policy fields (Nasiritousi and Linnér, 2014). At COP 20 in Lima, around 1,600 NGOs were accredited and admitted as observer organisations. ${ }^{3}$ These observer groups are clustered into nine constituencies with diverse but recognisable interests. A constituency is an assemblage of like-minded organisations with a chair and a focal point through which the Secretariat channels information. There are currently nine UNFCCC constituencies: business and industry NGOs (BINGOs), environmental NGO (ENGOs), research and independent NGOs (RINGOs), trade unions (TUNGO), indigenous people (IPOs), women and gender, youth (YOUNGOs), farmers, and local government and municipal authorities (LGMA) (UNFCCC, 2014). Another group of observer organisations is constituted by intergovernmental

\footnotetext{
${ }^{3}$ http://unfccc.int/parties and observers/items/2704.php
} 
organisations (IGOs). The constituencies mirror the nine major groups in the Agenda 21 process, which have been institutionalised in UN praxis on global environmental governance (Bäckstrand, 2006). The UNFCCC has adopted this system of organising civil society into constituencies to facilitate coordination and interaction (Munoz Cabré, 2011).

This article analyses unique survey data collected at four consecutive UNFCCC COPs - in Durban 2011, Doha 2012, Warsaw 2013 and Lima 2014. In our sample we had responses from both state and non-state delegates. The observer groups that we present in our analysis are business, researchers, environmental NGOs, local governments and IGOs; those groups that had too few respondents to include in our statistical analysis were placed in a category named 'Other'. First, we account for which of the three rationales that are reflected in participants' own perceptions. Second, we analyse whether geographical origin and actor type in the international policy-making process affect the extent to which these rationales are favoured.

The dataset consists of a total of 1,843 completed questionnaires collected at UNFCCC COPs 17-20. The survey was conducted by the International Negotiations Survey and targeted participants in: official side-events during both weeks of COPs 1720, and a quota sample (Bryman, 2012) of 496 COP 18 participants, with 394 answering this survey item correctly and being included in this study. Side-events take place in conjunction with the official negotiations and provide a platform for different actors to 
present their work and highlight issues for discussion. We decided to target side-event participants, since they have relatively high familiarity of NSA activities (Lovell, 2007; Schroeder and Lovell, 2012) and side-event participants have previously been successfully tapped on their expectations of corporate climate action (Buhr and Hjerpe, 2012), functions of side-events (Hjerpe and Linnér, 2010) and governance activities performed by NSAs (Nasiritousi et al., 2014a). To validate the responses obtained from side-event surveys, we also collected data from delegates at the main venue at COP 18 , where we followed a quota sampling approach (Bryman, 2012). Here, the researchers' experience and expectations are utilised to select strata in terms of geographical regions and actor types in the climate negotiations; which are carefully compared to the frame population. The frame population, in this case primarily the shares of government, NGO and IGO representatives, becomes available through the preliminary list of participants at the beginning of each COP. Our interviewers subsequently approach participants at the COP within each stratum to fill up the quotas to obtain a sample that reflects the population. Geographic strata have been formed based on participant data covering several years. In distributing the questionnaires, we cover different locations at the conference venue in order to encounter a wide variety of participants. Through the daily distribution of questionnaires over the two weeks of each COP, and through other measures that seek to reduce the sampling bias, we strive to obtain a sample that is as representative as possible (see Hjerpe and Nasiritousi, 2015). 
In order to answer the first question posed in this article — to what extent do the arguments of participants in international policy-making on climate change of why NSAs should be included resonate with the three rationales - the following question was posed in the survey: "Which reason, if any, is in your view the most important for including NSAs in the international policy-making process? Please tick only one." Respondents answered by indicating one of these response options:

- they provide information and expertise;

- they represent interests that have an important stake in the decisions;

- they voice marginalised views; and

- it is not important to include NSAs in the international policy-making process.

Respondents could also mark an option 'Other' and elaborate their argument in free text. ${ }^{4}$ These response options were designed to capture the main elements of the three normative arguments, respectively, while allowing participants to elaborate on their views.

The survey also contained questions about the respondents' primary role at the COP meeting and geographical origin; this enables us to analyse the second question -

4 Responses that indicated more than one option were excluded from the final sample and, consequently, the statistical analysis. We were unable to discern any systematic differences in terms of actor type or geographical region between these respondents and the ones included in the final sample. 
whether actor type and geographical origin affect the extent to which the arguments on non-state inclusion resonate with the three rationales. In terms of actor types, 231 were negotiators, 262 representatives from national government agencies, 44 from local governments, 128 from UN bodies or other intergovernmental organisations, 406 from environmental NGOs, 128 from business NGOs and 270 from research NGOs. We classified 368 responses in a category labelled Other, containing responses from, inter alia, journalists, trade unions, indigenous peoples, youth groups, women's NGOs, farmers' organisations, development NGOs, faith-based organisations and technical staff. Geographically the respondents resided in all six major world regions. While not representative for the average COP participant, the sample is nevertheless heterogeneous enough to capture respondents from different actor types and geographical regions to test for statistically significant differences.

Overall significance for categorical data was examined using Pearson chisquare $\left(\chi^{2}\right)$ tests. Chi-square tests of association were conducted on the data using the SPSS Crosstabs procedure to determine whether there is a relationship between responses to the question on arguments for NSA inclusion and actor type and region, respectively. ${ }^{5}$ Adjusted standardised residuals were used to test deviations from expected values separately for each $\chi^{2}$ test in the multiple contingency tables in order to explore what accounts for the association when statistical significance was found. Chi-

\footnotetext{
${ }^{5}$ Gender was also tested but this variable showed no significant association with responses to the question on arguments for NSA inclusion.
} 
square tests were used rather than multinomial logistic regression because of the nature of the data, with both dependent and independent variables being categorical, and because the aim of the analysis is to explore relationships rather than to predict probabilities of possible outcomes. With two independent variables, we included weights in our analysis to take into account differences in composition. In other words, we compensated for differences in terms of geographical composition when testing for differences across primary role categories, and in terms of composition of primary roles when testing for differences across geographical origin categories following the same method as Hjerpe and Nasiritousi (2015).

\section{Arguments for non-state inclusion in international policy-making processes}

Let us begin by examining how the three normative arguments for NSA inclusion in international policy-making: functionalism, neocorporatism and democratic pluralism fit with respondents' perceptions. Table 1 contains the percentages of the respondents who stated a preference for each particular argument for NSA inclusion in international policy-making on climate change at COP 17, COP 18, COP 19 and COP 20.

Although the data cover four years, the temporal robustness is nothing but remarkable and the question generates a distinct response. Overall, about half of the respondents indicate that NSAs should be included in international policy-making because they represent important stakes that are affected by the decisions. This suggests 
strong support for the neocorporatist rationale for NSA inclusion among participants of the UN climate change conferences. NSAs' ability to provide information and expertise is selected as the main reason by one third of the respondents, which indicates a moderate degree of support for the functionalist rationale. About one sixth of the respondents indicate that NSAs should be included because they represent marginalised voices and perspectives. Very few of the respondents, $3 \%$, state that it is not important to include NSAs in international policy-making processes. All of the above findings were found to be robust over time and amongst respondents both at the side-events and in the overall COP survey. 
Table 1. Respondents' preferences for reasons for inclusion of non-state actors in international policy-making processes at COP 17-20, \%.

\begin{tabular}{|c|c|c|c|c|c|}
\hline $\begin{array}{l}\text { COP17 SE } \\
(n=306)\end{array}$ & $\begin{array}{l}\text { COP18 } \\
(n=340)\end{array}$ & $\begin{array}{l}\text { COP18 } \\
(n=394)\end{array}$ & $\begin{array}{l}\text { COP19 SE } \\
(n=437)\end{array}$ & $\begin{array}{l}\text { COP20 SE } \\
(n=366)\end{array}$ & $\begin{array}{l}\text { All COPs } \\
(n=1,843)\end{array}$ \\
\hline $5 \%$ & $3 \%$ & $4 \%$ & $1 \%$ & $3 \%$ & $3 \%$ \\
\hline $31 \%$ & $31 \%$ & $36 \%$ & $28 \%$ & $34 \%$ & $32 \%$ \\
\hline $49 \%$ & $52 \%$ & $45 \%$ & $54 \%$ & $50 \%$ & $50 \%$ \\
\hline $15 \%$ & $14 \%$ & $15 \%$ & $17 \%$ & $13 \%$ & $15 \%$ \\
\hline
\end{tabular}

(SE refers to side-event sample) 
We will now break down the data in order to gauge to what extent respondents' preferences of the three arguments are systematically linked to their geographical origin. Are preferences for the functionalist, neocorporatist or democratic pluralist rationales particularly strong in some world regions, or are the preferences evenly spread across world regions? As Table 2 shows there is a statistically significant relationship between responses to the question on rationale for NSA inclusion and region of origin of the respondents, but not to the extent that the general tendency towards a neocorporatist rationale as the most favoured is challenged in any of the six world regions we examined. Based on the post hoc test of adjusted standardised residuals we conclude the following. First, respondents from Africa are significantly less likely to support NSA inclusion on the basis that they provide information and expertise. This is slightly surprising, but perhaps reflects a sense among African respondents that climate diplomacy is already science-based and that vulnerable countries rely on non-state actors to push for climate change action rather than providing information and expertise. Second, respondents from Asia are significantly less likely to support NSA inclusion on the basis that they represent interests that have an important stake in the decisions and significantly more likely to support NSA inclusion on the basis that they voice marginalised views. These respondents are at the same time significantly more likely to hold the view that it is not important to include NSAs in the international policy-making process. This split result may reflect the large differences in countries in this world 
region, which includes powerful countries such as Japan and China, and more vulnerable countries such as Nepal and Cambodia. These countries have very different political systems and vary in the degree to which they feel marginalised in climate diplomacy. Third, respondents from North America are significantly less likely to support NSA inclusion on the basis that they voice marginalised views. This is also true for respondents from Europe; however these respondents are also significantly less likely not to support NSA inclusion in international policy-making processes. In these two regions, respondents appear to place greater emphasis on output legitimacy over input legitimacy. 
Table 2. Cross-tabulation of responses to survey question on most important argument for including non-state actors in international policymaking process at COPs 17-20 by region of origin of respondent, in percent.

\begin{tabular}{|c|c|c|c|c|}
\hline $\operatorname{Region}(\mathrm{N})$ & $\begin{array}{c}\text { Not important to } \\
\text { include NSAs }\end{array}$ & $\begin{array}{l}\text { Information and } \\
\text { Expertise }\end{array}$ & $\begin{array}{l}\text { Represent interests with } \\
\text { important stakes }\end{array}$ & $\begin{array}{c}\text { Voice marginalised } \\
\text { views }\end{array}$ \\
\hline Africa (285) & $4 \%$ & $24 \% * *$ & $54 \%$ & $18 \%$ \\
\hline Asia (389) & $5 \% *$ & $33 \%$ & $43 \% * *$ & $19 \% * *$ \\
\hline Europe (502) & $1 \% *$ & $36 \%$ & $51 \%$ & $12 \% *$ \\
\hline North America (290) & $3 \%$ & $38 \%$ & $48 \%$ & $11 \% *$ \\
\hline South and Latin America (210) & $2 \%$ & $30 \%$ & $53 \%$ & $15 \%$ \\
\hline Oceania (47) & $2 \%$ & $28 \%$ & $57 \%$ & $13 \%$ \\
\hline Total $(1,723)$ & $3 \%$ & $33 \%$ & $49 \%$ & $15 \%$ \\
\hline
\end{tabular}

Pearson's chi-squared test $\chi^{2}=41 \mathrm{df}=15 . \mathrm{p}=0.000 * *$

Legend: Results of the test of the adjusted standardised residuals show which cells have a major influence on the significant chi-square test statistic. Cells with significant standardised adjusted residuals are indicated by stars (marked with $*$ at the $5 \%$ and $* *$ at the $1 \%$ significance level). The analysis has taken into account variations in actor types in the different regions in the sample. Some respondents did not indicate country of residence and/or primary role. Accordingly, the total number of respondents in table $3(1,725)$ differs. 
Let us now explore whether the respondents' roles in international policy-making on climate change influence their arguments for NSA inclusion by breaking down the data into different actor types; are the preferences for the functionalist, neocorporatist or democratic pluralist rationales particularly stronger or weaker for any of these actor types?

As shown in Table 3, different actor groups place varying degrees of emphasis on the different rationales for NSA inclusion, even though the neocorporatist rationale remains most favoured overall, although it is equally valued as functionalism amongst negotiators. The data shows the following results: First, the ordering of the responses of four actor types, environmental NGOs, intergovernmental organisations, researchers and Other, are similar and clearly suggest an ordering with inclusion on the basis that they represent interests that have an important stake in the decisions, then providing information and expertise, through to voice marginalised views and to the least extent that NSAs should not be included. Second, negotiators and national government representatives attribute about as high weight to inclusion based on providing information and expertise as inclusion on the basis that they represent interests that have an important stake in the decisions. This is an interesting finding, but perhaps not unexpected if we think of the inclusion of experts as being in line with intergovernmental neo-functionalism, which negotiators and government representatives are expected to support. Third, two actor groups express about as strong 
support for the option not to include NSAs in international policy-making as inclusion based on voicing marginalised views: local government and business NGOs. This may be an indication that these actor groups do not feel marginalised and have other avenues to interact with policy-makers outside formal channels. Generally, the more participatory models for NSA inclusion - neocorporatism and democratic pluralism appear to be associated to a greater extent with representatives of intergovernmental organisations, environmental NGOs and those in the Other category, such as youth representatives (over 67\% support one of these options).

Table 3 also shows that there is a statistically significant relationship between responses to the question on argument for NSA inclusion and actor type. The post hoc test of adjusted standardised residuals suggests the following. First, negotiators and national governments are significantly more likely to support NSA inclusion on the basis that they provide information and expertise. Negotiators are also significantly less likely to support NSA inclusion on the basis that they represent interests that have an important stake in the decisions. Second, representatives of business and industry groups are significantly less likely to support NSA inclusion on the basis that they voice marginalised views, and significantly more likely not to support NSA inclusion in the international policy-making process. Third, respondents from environmental NGOs are significantly more likely to support NSA inclusion on the basis that they represent interests that have an important stake in the decisions, significantly less likely to support 
NSA inclusion on the basis that they provide information and expertise, and significantly less likely not to support NSA inclusion in international policy-making processes. Fourth, respondents in the Other category are significantly more likely to support NSA inclusion on the basis that they voice marginalised views, and significantly less likely to support NSA inclusion on the basis of expertise. These results starkly show that while negotiators and national government representatives value NSA inclusion on the basis of information and expertise, environmental NGOs and Other respondents place higher emphasis on NSA inclusion based on representing interests with important stakes and voicing marginalised views. This highlights again a split between actors in how they view the rationale for NSA inclusion, one that is more instrumental among policy-makers and one that emphasises a political, democratic role for NSAs among some NGO respondents. 
Table 3. Cross-tabulation of responses to survey question on argument for including non-state actors in international policy-making process at COPs 17-20 by actor type, in percent.

\begin{tabular}{|c|c|c|c|c|}
\hline Actor type (N) & $\begin{array}{l}\text { Not important to } \\
\text { include NSAs }\end{array}$ & $\begin{array}{l}\text { Information and } \\
\text { Expertise }\end{array}$ & $\begin{array}{l}\text { Represent interests } \\
\text { with important } \\
\text { stakes }\end{array}$ & $\begin{array}{c}\text { Voice marginalised } \\
\text { views }\end{array}$ \\
\hline Negotiator (210) & $4 \%$ & $40 \% *$ & $40 \% * *$ & $16 \%$ \\
\hline National government (239) & $3 \%$ & $38 \% *$ & $44 \%$ & $15 \%$ \\
\hline Local government (42) & $7 \%$ & $31 \%$ & $55 \%$ & $7 \%$ \\
\hline Business and industry (126) & $6 \% * *$ & $37 \%$ & $52 \%$ & $5 \% * *$ \\
\hline Researcher (264) & $3 \%$ & $36 \%$ & $48 \%$ & $13 \%$ \\
\hline Intergovernmental organisation (114) & $1 \%$ & $32 \%$ & $53 \%$ & $14 \%$ \\
\hline Environmental NGO (390) & $1 \% *$ & $29 \% *$ & $55 \% *$ & $15 \%$ \\
\hline Other $(340)$ & $2 \%$ & $26 \% * *$ & $51 \%$ & $21 \% * *$ \\
\hline Total $(1,725)$ & $3 \%$ & $33 \%$ & $49 \%$ & $15 \%$ \\
\hline
\end{tabular}

Pearson's chi-squared test $\chi^{2}=57 \mathrm{df}=21 . \mathrm{p}=0.000 * *$

Legend: Results of the test of the adjusted standardised residuals show which cells have a major influence on the significant chi-square test statistic. Cells with significant standardised adjusted residuals are indicated by stars (marked with $*$ at the $5 \%$ and $* *$ at the $1 \%$ significance level). The analysis has taken into account variations in region of origin in the actor groups in the sample. Some respondents did not indicate country of residence and/or primary role. Accordingly, the total number of respondents in table $2(1,723)$ differs. 


\section{Other Reasons for NSA Inclusion in International Policy-Making Processes}

The survey data shows a strong preference for NSA inclusion in international policymaking processes based on the view that they represent interests that have an important stake in the decisions. At the same time it reveals differences in support for the three rationales depending on actor type and geographical origin, but not to the extent that the general pattern of support for the neocorporatist rationale is challenged. While the survey data enriches our understanding of how perceptions on the role and contributions of NSAs diverge between actor types, it cannot capture the full range of views about arguments for NSA inclusion in international policy-making processes due to how the survey questions were formulated, given space constraints and simplifications to make them sufficiently easy to answer. Nevertheless, the Other option in the survey question allows for participants to elaborate more fine-tuned arguments for why they think NSAs should be included in international affairs.

An analysis of these free text responses shows that they generally complement the survey response options by highlighting other aspects of the functionalist, neocorporatist and democratic pluralist rationales that were not captured by the survey question. For example, in accordance with the functionalist approach, some respondents highlight the ability to NSAs to provide 'non-biased' information by providing independent and 'balanced' views that are 'out of political influences'. According to 
these respondents, NSAs should be included in the international policy-making process because they are non-political and solutions-oriented.

Other respondents elaborate in line with a neocorporatist rationale where NSAs are seen as facilitators for the implementation of decisions: 'They could be more efficient and quick in the implementation of actions than states alone', 'They are key to speed up diffusion and implementation of politics' and they facilitate 'implementation at the community level'. These respondents thus favour NSA inclusion based on the view that states could benefit from the participation of sectorial organisations that drive change on the ground. A few respondents, however, express suspicion of NSAs because they represent special, biased interests: 'It is important to be cautious with NSAs because they have interests'. This view thus contradicts the non-biased assessment of NSAs found in the functionalist approach and instead highlights NSAs' roles as political actors.

A third set of responses highlights the broader role of NSAs as democratising agents, in terms of improving the discursive quality and increasing transparency and accountability in international affairs in line with deliberative accounts of democracy (Stevenson and Dryzek, 2014). For example, 'They give a voice to public interest' and they 'Work to take in account forgotten issues', as well as 'serve as watchdogs', 'keep governments accountable', and 'translate complex text of negotiators to comprehensible perspectives for ordinary yet affected people'. A few also mention that NSAs can 
pressure states into taking action: 'They put pressure on politicians while political will is missing'.

Thus these responses confirm the arguments found in the literature on NSA inclusion about their potential roles as participants in international affairs and highlight the key tensions about whether they have an apolitical role, or represent sectorial interests, or speak on behalf of the public interest or the voiceless.

\section{Discussion}

How should we understand the empirical findings regarding arguments for NSA inclusion that were obtained through the survey of actors' perceptions? Let us begin by recapitulating that even if the neocorporatist rationale finds strong support in the empirical material, the two other rationales - functionalism and democratic pluralism also resonate with moderate segments in most actor types involved in international policy-making on climate change. About one third of the respondents indicated providing information and expertise compatible with a functionalist rationale for NSA inclusion. This is an instrumental view of NSA inclusion, in line with an emphasis on output legitimacy. The results indicate that this view particularly resonates with negotiators, national governments and business and industry representatives but also among North American and European respondents. The slightly elevated preferences of negotiators could be understood as a result of their favouring of apolitical NSAs or as 
seeking unbiased advice for making better decisions and facilitate the international policy-making process. Alternatively, it could reflect a desire for efficiency in the process among these actor groups. Previous studies have highlighted potential tensions between input and output legitimacy (Dingwerth, 2007). Participatory arrangements of the internal workings of the EU, for example, often favour rational outcomes over other participatory values (Wolff, 2013).

We also see a slight polarisation in the shares of respondents favouring the democratic pluralist rationale; Asian and African respondents attribute more weight to it whereas European and North American respondents as well as business and industry representatives, attribute less weight to it. The results, thus, indicate that those who are less likely to view themselves as being marginalised are also less likely to argue that NSAs be included based on their ability to bring marginalised views to the international policy-making process. Conversely, respondents from regions harbouring most of the least developed countries were more likely to favour inclusion based on marginalised views. These respondents may thus perceive an important role for NSAs in balancing supposed or real injustices in international policy-making processes. An example of this is that some delegations from developing countries receive assistance from NGOs in presenting their positions at intergovernmental meetings (Raustiala, 1997).

In our view, one key to understanding the diverging perceptions of what NSAs do and should do in international affairs is to recognise the heterogeneous nature of the 
NSA groups that participate in international policy-making on climate change. While some of the NSAs focus their activities on providing independent information, others lobby for particular interests, while yet others seek to promote general values of justice and fairness. Many - if not most - NSA groups undertake more than one of these tasks but may face different levels of success in combining them. Nasiritousi et al. (2014a), for example, find that different NSAs are perceived to have distinct governance profiles that either centre around i) influence and action, ii) ideas and expertise, or iii) awareness raising and representation, but not all three combined. The NSA respondents do not appear to have answered the survey question based on self-justification, however. For example, researchers surprisingly do not highlight information and expertise to as high a degree as could be expected.

Why, then, do the survey results indicate a strong overall support for the neocorporatist rationale that NSAs should be included on the basis that they represent interests that have an important stake in the decisions? This is an important question since the strong overall support for the neocorporatist rationale for NSA inclusion may have implications for which types of NSAs become most actively engaged in international policy-making. There are several reasons why a neocorporatist rationale could be à la mode: it could either signify a general trend of changing governmental rationalities or it could reflect developments that are particular to global environmental governance. 
The former argument is supported by observations in the literature of " $a$ changing logic or rationality of government" (Sending and Neumann, 2006: 652), whereby states and international organisations increasingly govern through the involvement of NSAs, both at the domestic and international levels. A sign of this is the increasing emphasis on involving stakeholders in different global policy-processes, for example through multi-stakeholder dialogues and by encouraging voluntary partnerships between different types of actors (Khanna, 2012).

On the other hand, our empirical findings may reflect the particular context of global environmental governance, where there is already relatively strong input legitimacy in terms of observer participation and transparency provisions but an implementation gap, whereby the outcomes of years of gridlocked negotiations have not measured up to the perceived needs (Victor, 2011). This may explain the general emphasis on output legitimacy over input legitimacy amongst our survey respondents.

For example, we believe that the neocorporatist rationale is compatible with the open accreditation policy of the UNFCCC for inclusion of observers. This enables any organisation that fulfils the general requirements for accreditation to participate at these meetings. The increasing numbers and types of non-state organisations attending these conferences (e.g. Muñoz Cabré, 2011), an increasing heterogeneity of the topics they raise (Hjerpe and Buhr, 2014; Nasiritousi et al., 2014b), and a will or necessity to link their topics to climate change (e.g. Jinnah, 2011), are all factors that are likely to foster a 
culture of identifying oneself as a stakeholder or, at least, a culture that awards organisations that do well in presenting themselves as an important stakeholder. In this regard, Muñoz Cabré, (2011) concluded that certain issues and organisations dominate NSA participation in the UNFCCC, namely environment and conservation, and academic, business and energy NGOs, while many issues are voiced by only a few organisations. This means that in practise some interests are more dominant than others.

One important way in which NSAs are engaging in the international policymaking process is through so-called 'constituencies' (e.g. UNFCCC, 2014; Schroeder and Lovell, 2012). As mentioned above, this is a system of representation of non-state actors that has its roots in the Agenda 21 process and has since been institutionalised in UN praxis on global environmental governance (Bäckstrand, 2006). In recent years there have been signs of the constituencies shouldering a more active role in the international policy-making process. The number of interventions by the constituencies at COP 16 was higher than in COP 15 for all constituencies except RINGOs and farmers (Endo pers comm). Moreover, in the proposals for enhanced observer participation in the UNFCCC, high-level multi-stakeholder dialogues have been suggested as one way of improving NSA involvement in the policy-making process (UNFCCC, 2012). These are all signs that are well in line with Williamson's (1985) understanding of neocorporatism as continuous and structured participation of interest organisations in the policy-making process. 
The strong overall support for the neocorporatist rationale among our respondents may also reflect the relative stalemate of the intergovernmental negotiations since COP 15 in Copenhagen. In the aftermath of Copenhagen there has been an increasing recognition that not only states but a wider array of stakeholders need to join forces to be able to achieve the required emission reductions (e.g. UNFCCC, 2013). This is also likely to foster a culture of many stakeholders around the negotiation table. Since 2012, the Co-Chairs of the Ad Hoc Working Group on the Durban Platform for Enhanced Action (ADP) have convened several special events whereby constituency representatives have been "invited to explore in more concrete ways the potential role, involvement and contributions of non-State actors in the context both of the 2015 agreement and of pre-2020 ambition" (UNFCCC, 2013: para. 1). Strengthened engagement with different NSAs to ensure effective climate action is also highlighted in the Lima-Paris Action Agenda. ${ }^{6}$

However, we have reasons to believe that the strong overall support for the neocorporatist rationale extends beyond climate diplomacy. In a previous study, we found support for the neocorporatist rationale among 477 participants in the UN Conference on Sustainable Development (UNCSD) in Rio, 2012 (www.internationalnegotiationssurvey.se). Employing the same survey question on most important reason to include NSAs in international policy-making, interestingly $56 \%$

\footnotetext{
${ }^{6}$ http://climateaction.unfccc.int/aboutlpaa.aspx
} 
of the UNCSD respondents indicated this was to represent important stakes, $31 \%$ to provide information and expertise, and $11 \%$ to represent marginalised views, while $2 \%$ thought it was not important to include non-state actors. This finding suggests that the reach of the neocorporatist rationale goes beyond the confines of the UNFCCC.

Overall these results indicate that the type of participatory governance model that is envisaged by a range of states and NSAs may resemble that proposed in descriptions of global stakeholder democracy, whereby policy-making processes include an element of deliberation among stakeholder representatives (Macdonald, 2008). While decision-making remains in the hands of states, this type of model foresees a political role for stakeholders in representing interests that have an important stake in the decisions. Thus, one important implication of the widespread support of the neocorporatist rationale is that NSAs are viewed as political actors in their own right and that the evolving practice of NSA participation may favour those organisations that are particularly strong in representing interests and contributing to output rather than input legitimacy. This raises important questions about how to identify legitimate representatives of interests and how to reconcile stakeholder representation with other values associated with input legitimacy. 


\section{Conclusions}

This paper set out to empirically explore the views of different actors on which among three normative arguments for NSA inclusion in international policy-making processes - functionalist, neocorporatist, and democratic pluralist - they support. Specifically, we tested to what extent geographical origin and actor type affected the extent to which the three rationales are indicated among a sample of participants at the UNFCCC climate change conferences.

The survey results clearly show that the participation norm is strong in global environmental governance. This is indicated particularly by the high share of respondents that express that NSAs should be included on the basis that they represent interests with important stakes in the decisions. This result is stable over time, across world regions and is valid for all actor types, except negotiators, who attribute the same weight to the functionalist rationale of providing information and expertise. High support for the neocorporatist rationale indicates a strong instrumental view of NSA participation, which emphasises that NSAs can contribute to output legitimacy in terms of improving the performance and efficiency of policy-making processes.

Given the scope of our study, with our empirical analyses focusing on the international climate change negotiations, we cannot determine whether our survey respondents' views signify a general change in governmental rationalities or whether they represent developments that are particular for global environmental governance. 
For instance, the perhaps surprisingly low support for the argument that NSAs should be included because they provide information and expertise may reflect the fact that the Intergovernmental Panel on Climate Change (IPCC) already plays this role, conceivably making it less necessary for other NSAs to fill this function. On the other hand, the same survey question posed at the United Nations Conference on Sustainable Development (Rio+20) in $2012^{7}$ showed similar results, perhaps reflecting the impact of the Agenda 21 process whereby the UN's system of representation of non-state actors through major groups and constituencies strengthens the neocorporatist rationale in global environmental governance.

Future research could thus explore whether the strong overall support for the neocorporatist rationale for NSA inclusion can be found in other policy fields and across different policy-cycles. Another avenue for future studies is to explore alternative question formats for capturing perceptions of rationales for NSA inclusion, perhaps asking about other rationales (e.g. the transparency aspect of NSA inclusion) or posing these questions to a wider audience. Moreover, future research could offer more finetuned analysis of geographical differences based on domestic political systems and other relevant factors. This paper has offered a first analysis of perceptions of NSA participation in international policy-making focusing on climate diplomacy and has

7 http://www.internationalnegotiationssurvey.se/survey-items/non-state-actors-in-climate-changegovernance-2/ 
raised a number of issues related to legitimacy and democratic accountability worthy of further investigation.

What is clear is that the open accreditation policy of the UNFCCC and other global environmental governance institutions more generally enables a multitude of NSAs to perform different roles on the international stage. Whether the strong overall support for the neocorporatist rationale leads to democratisation through global stakeholder models remains an open question - one with profound and interesting implications.

\section{Acknowledgments}

We would like to thank two anonymous reviewers for excellent comments, Lars Valter, Åsa Danielsson and Richard Öhrvall for valuable suggestions, and colleagues in the International Negotiations Survey team who assisted in handing out questionnaires during COP17- COP20.

\section{Funding}

This research was made possible through generous grants from the Swedish Research Council (Project No. 421-2011-1862) and Formas (Project No. 2011-779) for the 
research project non-state actors in the new landscape of international climate cooperation.

\section{References}

Adams B and Pingeot L (2013) Strengthening public participation at the United Nations for sustainable development: Dialogue, debate, dissent, deliberation, New York: UN DESA/DSD Major Groups Programme.

Anderson K and Rieff D (2005) "Global civil society": a sceptical view. In Anheier H, Glasius M, Kaldor M (eds) Global Civil Society 2004/2005, London: Sage, 26-39. Archibugi D, Koenig-Archibugi M and Marchetti R (eds) (2011) Global Democracy. Normative and Empirical Perspective, Cambridge: Cambridge University Press.

Bernauer T and Gampfer R (2013) Effects of civil society involvement on popular legitimacy of global environmental governance. Global Environmental Change 23(2): 439-449.

Bernstein S (2005) Legitimacy in global environmental governance, Journal of International Law and International Relations 1(1-2): 139-66.

Bernstein S (2012) Legitimacy problems and responses in global environmental governance. In: Dauvergne P (ed) Handbook of Global Environmental Politics. Cheltenham, UK: Edward Elgar, 147-162. 
Betsill M and Corell E (2008) NGO Diplomacy. The Influence of Non-Governmental Organizations in International Environmental Organizations. Cambridge, MA: The MIT Press.

Biermann F and Gupta A (2011) Accountability and legitimacy in earth system governance: A research framework. Ecological Economics 70(11): 1856-1864.

Bryman A (2012) Social Research Methods. Oxford: Oxford University Press.

Buchanan A and Keohane R (2006) The Legitimacy of Global Governance Institutions, Ethics and International Affairs 20(4): 405-437.

Burton J (1975) Functionalism and the resolution of conflict. In: Groom A J R and Taylor P (eds.) Functionalism: Theory and Practice of International Relations. London: University of London Press, 238-249.

Brühl T (2010) Representing the People? NGOs in International Negotiations. In: Steffek J and Hahn K (eds.) Evaluating Transnational NGOs. Legitimacy, Accountability and Representation. Palgrave MacMillan, 181-199.

Buhr K and Hjerpe M (2012) Expectations on corporate climate action under regulatory uncertainty. International Journal of Climate Change Strategies and Management 4(4): 403-419.

Bäckstrand K (2015) Civil Society. In: Pattberg P and Zelli F (eds) Encyclopedia of Global Environmental Politics and Governance. Cheltenham, UK: Edward Elgar (in press). 
Bäckstrand K (2012) Democracy and Global Environmental Politics. In: P Dauvergne (ed.), Handbook of Global Environmental Politics, Cheltenham, UK and Northampton, MA, USA: Edward Elgar Publishing, pp. 507-19.

Bäckstrand K (2006) Democratizing Global Environmental Governance? Stakeholder Democracy after the World Summit on Sustainable Development. European Journal of International Relations 12(4): 467-498.

Carr DL and Norman ES (2008) Global civil society? The Johannesburg World Summit on Sustainable Development. Geoforum 39(1): 358-371.

Clark AM, Friedman EJ and Hochstetler K (1997) The sovereign limits of global civil society: a comparison of NGO participation in UN World Conferences on the environment, human rights and women. World Politics 51(1): 1-35.

Cerny P (2010) Rethinking World Politics. A Theory of Transnational Pluralism. Oxford: Oxford University Press.

Charnovitz S (1997) Two Centuries of Participation: NGOs and International Governance. Michigan Journal of International Law 18(2): 183-286.

Dingwerth K (2007) The new transnationalism: Private transnational governance and its democratic legitimacy. Basingstoke, UK: Palgrave Macmillan.

Dombrowski K (2010) Filling the Gap? An Analysis of Non-Governmental Organizations Responses to Participations and Representation Deficits in Global Climate Governance. International Environmental Agreements 10 (4): 397-416 
Dryzek JS (2012) Global Civil Society: The Progress of Post-Westphalian Politics. Annual Review of Political Science 15(1): 101-119.

Dryzek, J (2006) Deliberative Global Politics. Discourse and Democracy in a Divided Global World, Polity Press.

Friedman EJ, Hochstetler K and Clark A-M (2005) Sovereignty, Democracy and Global Civil Society. State-Society Relations at UN World Conference. New York: State University of New York Press.

Gough C and Shackley S (2001) The Respectable Politics of Climate Change: The Epistemic Communities and NGOs. International Affairs 77(2): 329-346.

Haas, P (1992) Introduction: epistemic communities and international policy coordination. International Organization 46 (1): 1-35.

Held, D (1995) Democracy and the Global Order. From the Modern State to Cosmopolitan Governance. Stanford, CA: Stanford University Press.

Hjerpe M and Buhr K (2014) Frames of Climate Change in Side Events from Kyoto to Durban. Global Environmental Politics 14(2): 102-121.

Hjerpe M and Linnér B-O (2010) The functions of side events in global climate change governance. Climate Policy 10(2): 167-180.

Hjerpe M and Nasiritousi N (2015) Views on alternative forums for effectively tackling climate change. Nature Climate Change 5(9): 864-867. 
Jinnah S (2011) Climate Change Bandwagoning: The Impacts of Strategic Linkages on Regime Design, Maintenance, and Death. Global Environmental Politics 11: 1-9. Keohane R (2011) Global Governance and Legitimacy, Review of International Political Economy 18(1): 99-109.

Khanna P (2012) How Multi-stakeholder is Global Policy?, Global Policy 3(3): 384390.

Lovell H (2007) More Efficient, Effective and Faster? The Role of Non-State actors at UN Climate Negotiations. Tyndall Briefing Note 24, Tyndall Centre for Climate Change Research, December 2007.

Macdonald T (2008) Global stakeholder democracy: power and representation beyond liberal states, Oxford: Oxford University Press.

Mitrany D (1975) The Functional Theory of Politics, New York: London School of Economics \& Political Science, St. Martin's Press.

Muñoz Cabré M (2011) Issue-linkages to Climate Change Measured through NGO Participation in the UNFCCC. Global Environmental Politics 11 (3):10-22.

Nasiritousi N and Linnér B-O (2014) Open or closed meetings? Explaining nonstate actor involvement in the international climate change negotiations. International Environmental Agreements: Politics, Law and Economics 1-18. doi:10.1007/s 10784-014-9237-6. 
Nasiritousi N, Hjerpe M and Linnér, B-O (2014a) The roles of non-state actors in climate change governance: understanding agency through governance profiles. International Environmental Agreements: Politics, Law and Economics 118. doi:10.1007/s10784-014-9243-8.

Nasiritousi N, Hjerpe M and Buhr K (2014b) Pluralising climate change solutions? Views held and voiced by participants at the international climate change negotiations, Ecological Economics 105, September: 177-184.

Payne RA and Samhat N (2004) Democratizing Global Politics. Discourse, Norms, International Regimes and Political Community, New York: State University of New York Press.

Raustiala K (1997) States, NGOs, and International Environmental Institutions, International Studies Quarterly 41(4): 719-740.

Rieff D (1999) The False Dawn of Civil Society. The Nation (February 22): 11-16.

Risse T (2004) Global Governance and Communicative Action, Government and Opposition 39 (2): 288-13.

Scharpf F (1997) Economic Integration, Democracy and the Welfare State. European Public Policy 4(1): 18-36.

Scholte JA (2004) Civil Society and Democratically Accountable Global Governance. Government and Opposition 39(2): 211-233. 
Scholte JA (ed.) (2011) Building Global Democracy. Civil Society and Accountable Global Governance. Cambridge: Cambridge University Press.

Schroeder H and Lovell H (2012) The role of non-nation state actors and side events in the international climate negotiations. Climate Policy 12(1): 23-37.

Sending OJ and Neumann IB (2006) Governance to Governmentality: Analyzing NGOs, States, and Power. International Studies Quarterly 50(3): 651-672.

Steffek J, Kissling C and Nanz P (eds) (2008) Civil Society Participation in European and Global Governance: A Cure for the Democratic Deficit? Basingstoke, Hampshire: Palgrave Macmillan.

Stevenson H and Dryzek JS (2014) Democratizing Global Climate Governance, Cambridge: Cambridge University.

Suchman MC (1995) Managing Legitimacy: Strategic and Institutional Approaches. Academy of Management Journal 20(3): 571-610.

Tallberg J (2010) Transnational Access to International Institutions: Three Approaches. In: Jönsson C and Tallberg J (eds) Transnational Actors in Global Governance: Patterns, Explanations, and Implications. Basingstoke, Hampshire: Palgrave Macmillan, 45-66.

Tallberg J and Jönsson C (2010) Transnational Actor Participation in International Institutions: Where, Why, and with What Consequences? In: Jönsson C and Tallberg J (eds) Transnational Actors in Global Governance: Patterns, 
Explanations, and Implications. Basingstoke, Hampshire: Palgrave Macmillan, 121.

Tallberg J, Sommerer T, Squatrito T and Jönsson C (2013) The Opening Up of International Organizations: Transnational Access in Global Governance. Cambridge: Cambridge University Press.

Tallberg J and Uhlin A (2011) Civil Society and Global Democracy: An Assessment. In: Archibugi D, Marchetti R, Koenig-Archibugi M (eds.) Global Democracy: Normative and Empirical Perspectives. Cambridge: Cambridge University Press, 210-232.

UNFCCC (2014) Non-governmental organization constituencies. Available at: http://unfccc.int/files/parties_and_observers/ngo/application/pdf/constituencies_a nd_you.pdf (accessed 12 June 2015).

UNFCCC (2013) Summary of the ADP Co-Chairs' special event, ADP 2, part 2, Bonn, Germany, June, Available at: http://unfccc.int/resource/docs/2013/adp2/eng/15infsum.pdf (accessed 2 April 2015).

UNFCCC (2012) Report of the Subsidiary Body for Implementation on its thirty-sixth session, held in Bonn from 14 to 25 May 2012, Available at: http://unfccc.int/resource/docs/2012/sbi/eng/15.pdf (accessed 12 June 2015).

Victor DG (2011) Global Warming Gridlock, Cambridge Univ Press, Cambridge, UK. 
Willetts P (2006) The Cardoso Report on the UN and Civil Society: Functionalism, Global Corporatism, or Global Democracy? Global Governance: A Review of Multilateralism and International Organizations 12(3): 305-324.

Willetts P (2011) Non-governmental Organizations in World Politics. The Constructions of Global Governance. London: Routledge.

Williamson P (1985) Varieties of Corporatism: Theory and Practice. Cambridge: Cambridge Univ. Press.

Wolff C (2013) Functional Representation and Democracy in the EU: The European Commission and Social NGOs. Colchester: ECPR. 